\title{
pPCV, a versatile vector for cloning PCR products
}

\author{
Christiane R Janner, Ana Lívia P Brito, Lidia Maria P Moraes, Viviane CB Reis and Fernando AG Torres*
}

\begin{abstract}
The efficiency of PCR product cloning depends on the nature of the DNA polymerase employed because amplicons may have blunt-ends or $3^{\prime}$ adenosines overhangs. Therefore, for amplicon cloning, available commercial vectors are either blunt-ended or have a single 3' overhanging thymidine. The aim of this work was to offer in a single vector the ability to clone both types of PCR products. For that purpose, a minimal polylinker was designed to include restriction sites for EcoRV and $X \mathrm{cml}$ which enable direct cloning of amplicons bearing blunt-ends or A-overhangs, respectively, still offering blue/white selection. When tested, the resulting vector, PPCV, presented high efficiency cloning of both types of amplicons.
\end{abstract}

Keywords: Polymerase chain reaction; Molecular cloning; Plasmid

\section{Introduction}

The in vitro amplification of DNA fragments by polymerase chain reaction (PCR) is a routine technique in most molecular biology laboratories. Direct cloning of DNA fragments amplified by Taq DNA polymerase has frequently been found to be inefficient [Harrison et al. 1994] since this enzyme tends to add a non-templated nucleotide to the $3^{\prime}$ ends of the amplicon, mostly an adenosine residue, leaving a 3'overhang [Clark 1988]. To circumvent this limitation, some commercially available vectors were constructed in order to have a $3^{\prime}-\mathrm{T}$ overhang (T-vectors) for sticky-end cloning. Many strategies have been developed to add a 3 ' -T overhang. One approach involves tailing a blunt-ended vector using terminal transferase in the presence of dideoxythymidine triphosphate (ddTTP) [Holton \& Graham 1991] but there is a high probability that some vector molecules will lack an overhang at one or both ends. These incomplete plasmids can circularize during ligation rendering ineffective for cloning [Jun et al. 2010]. Another approach is to digest a parental vector with a restriction enzyme that will generate single $3{ }^{\prime}-\mathrm{T}$ overhangs. Restriction enzymes used for that purpose include BciVI, BfiI, HphI, MnlI, TaaI, XcmI and Eam1105I [Jun et al. 2010; Dimov 2012; Gu \& Ye 2011; Borovkov \& Rivkin 1997]. However, these vectors are not recommended for cloning amplicons produced by DNA polymerases which generate blunt-ended products.

\footnotetext{
* Correspondence: ftorres@unb.br

Centro de Biotecnologia Molecular, Departamento de Biologia Celular, Universidade de Brasília, Brasília, DF 70910-900, Brazil
}

The aim of this work was to construct a vector based on pBlueScript ${ }^{\circ}$ II KS with a modified polylinker which would allow direct cloning of PCR products bearing either blunt-ends or A-overhangs.

\section{Materials and methods}

\section{Strain and media}

Escherichia coli XL10-Gold and DH5 $\alpha$ were used for routine DNA manipulations. Bacterial cells were cultured in LB medium $(0.5 \%$ yeast extract, $1 \%$ peptone and $1 \%$ $\mathrm{NaCl}$ ) supplied with $100 \mu \mathrm{g} / \mathrm{ml}$ of ampicillin, $0.1 \mathrm{mM}$ IPTG and $0.004 \%$ X-Gal (5-bromo-4-chloro-3-indolyl- $\beta$ D-galactopyranoside) when necessary. Genomic DNA of Saccharomyces cerevisiae S288c (MATa SUC2 mal gal2 mel flo1 flo8-1 hap1 ho bio1 bio6) [Mortimer \& Johnston 1986] was used as template for amplification of the LEU2 gene.

\section{Construction of T-vector}

The stuffer DNA used in this work was derived from a fragment of the $S$. cerevisiae URA3 gene present in plasmid pNKY51 [Alani et al. 1987] and was obtained by PCR using the following primers: PXCM-1 (5'-AAGGTACCGATAT CTCCAATACTTGTATGGAGGGCACAGTTAAGCC-3') and PXCM2 (5'-AAGAGCTCGATATCCTCCAATACTC CTTTGGATCCCTTCCCTTTGCAAATAGT-3'). Primer PXCM-1 contains restriction sites for SacI, EcoRV and $X c m \mathrm{I}$ while PXCM-2 has sites for KpnI, EcoRV and XcmI (all sites are underlined). Both primers have sequences complementary to URA3 which allow amplification of

\section{望}




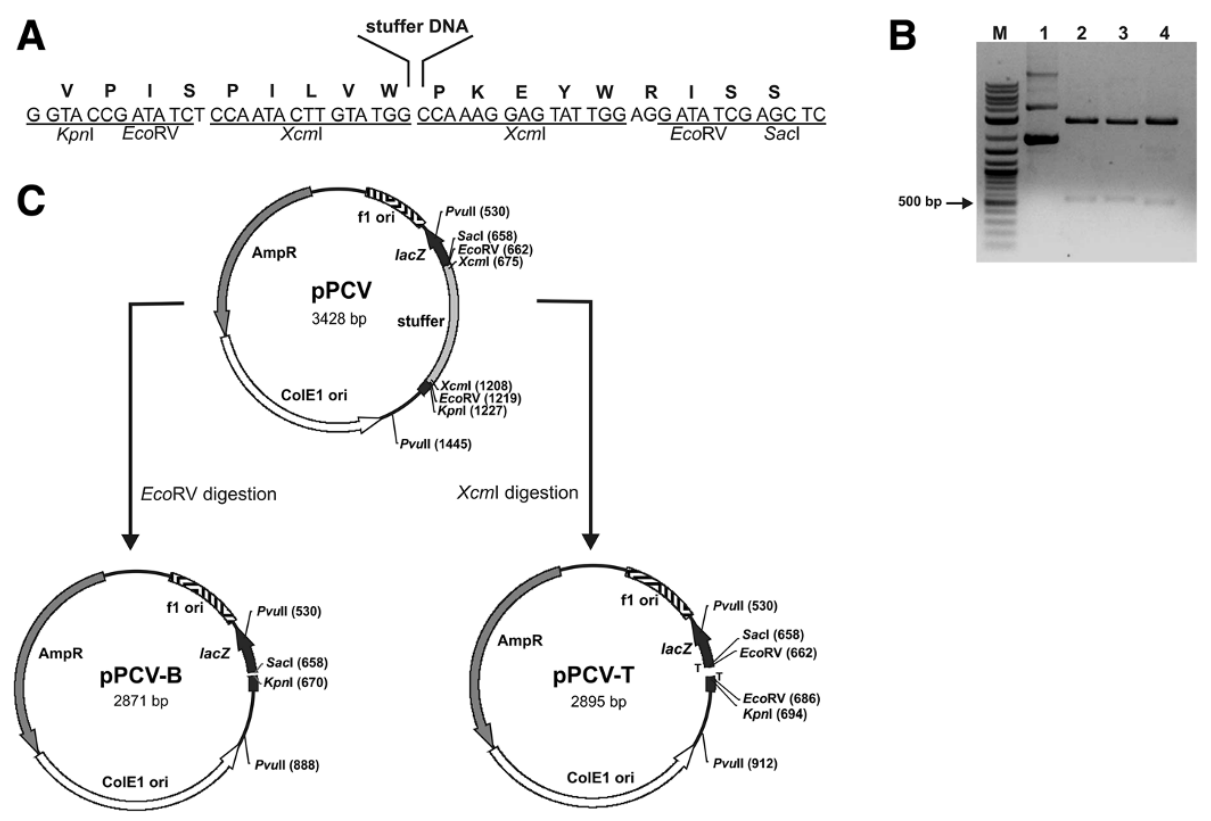

Figure 1 Construction of pPCV. (A) Restriction sites and predicted lacZa reading frame present in pPCV (B) Restriction analysis of pPCV. Lanes: M-2log molecular weight marker (New England Biolabs); 1-intact pPCV; 2-pPCV digested with EcoRV; 3-pPCV digested with Sacl and Kpnl; 4-pPCV digested with Xcml. (C) Physical map of pPCV and its linearized forms PPCV-T and PPCV-B.

a $~ 600$ pb stuffer DNA fragment. PCR was carried out in a volume of $50 \mu \mathrm{L}$ containing $1.5 \mathrm{ng}$ pNKY51, $0.2 \mathrm{mM}$ dNTP, $0.2 \mu \mathrm{M}$ each primer, $1 \times$ PCR buffer (100 mM Tris-HCl [pH 8.5], $500 \mathrm{mM} \mathrm{KCl),} 2 \mathrm{mM}$ $\mathrm{MgCl}_{2}$ and $2 \mathrm{U}$ Taq polymerase (LCG Biotechnology). Amplification was performed for 30 cycles of $94^{\circ} \mathrm{C} / 45 \mathrm{~s}$, $65^{\circ} \mathrm{C} / 45 \mathrm{~s}, 72^{\circ} \mathrm{C} / 40 \mathrm{~s}$ after an initial denaturation step of $94^{\circ} \mathrm{C} / 45 \mathrm{~s}$. A final extension step was performed for $2 \mathrm{~min} / 72^{\circ} \mathrm{C}$. The resulting amplicon was purified with UltraClean PCR Clean-Up Kit (MO BIO) and digested with $S a c$ I and $K p n I$ following ligation to pBlueScript ${ }^{\oplus}$ II KS digested with the same enzymes.

\section{Cloning efficiency}

To test cloning efficiency of both vectors, the $S$. cerevisiae LEU2 gene was cloned after amplification from yeast genomic DNA using Taq polymerase (Invitrogen) or Phusion (Finnzymes) and primers 5-leud (5'-GAGATCTATATAT ATTTCAAGGATATACCATTCTAATG-3') and 3-leud (5'-GAGATCTGTTTCATGATTTTCTGTTACACC-3'). Both amplification reactions were carried out in a volume of $50 \mu \mathrm{L}$. For amplification with Taq polymerase, $10 \mathrm{ng}$ genomic DNA was added to a reaction which included $1 \times$

Table 1 Cloning efficiency of pPCV

\begin{tabular}{lcc}
\hline System & \% White colonies & \% Recombinant clones \\
\hline PPCV-B & $4.7 \%$ & $83.3 \%$ \\
pPCV-T & $92.2 \%$ & $90.0 \%$ \\
\hline
\end{tabular}

PCR buffer (200 mM Tris- $\mathrm{HCl}$ [pH 8.4], $500 \mathrm{mM} \mathrm{KCl),}$ $2 \mathrm{mM} \mathrm{MgCl}_{2}, 0.2 \mathrm{mM}$ dNTP mixture, $0.2 \mu \mathrm{M}$ each primer and $2 \mathrm{U}$ Taq polymerase. The reaction was performed for 30 cycles of $94^{\circ} \mathrm{C} / 45 \mathrm{~s}, 55^{\circ} \mathrm{C} / 30 \mathrm{~s}, 72^{\circ} \mathrm{C} / 1.5 \mathrm{~min}$ after an initial denaturation of $94^{\circ} \mathrm{C} / 45 \mathrm{~s}$. The final extension was accomplished for $10 \mathrm{~min} / 72^{\circ} \mathrm{C}$. The PCR system with Phusion was carried out with $10 \mathrm{ng}$ genomic DNA, 1× Phusion HF buffer (1.5 mM $\mathrm{MgCl}_{2}$ ), $0.2 \mathrm{mM} \mathrm{dNTP}$, $0.5 \mu \mathrm{M}$ each primer and $0.5 \mathrm{U}$ Phusion DNA polymerase. The PCR program was: $30 \mathrm{~s}$ at $98^{\circ} \mathrm{C}$ for initial denaturation following 30 cycles of $98^{\circ} \mathrm{C} / 10 \mathrm{~s}, 61^{\circ} \mathrm{C} / 30 \mathrm{~s}, 72^{\circ} \mathrm{C} /$ $30 \mathrm{~s}$ with a final extension of $72^{\circ} \mathrm{C} / 5 \mathrm{~min}$. PCR products were purified as described previously and ligated into the constructed cloning vectors. Ligation was carried out in a final volume of $10 \mu \mathrm{L}$ with a vector:insert ratio of 1:5. The system included $1 \mathrm{U}$ of T4 DNA ligase (USB) and $1 \times$ reaction buffer (66 $\mathrm{mM}$ Tris $-\mathrm{HCl}[\mathrm{pH} 7.6], 6.6 \mathrm{mM}$

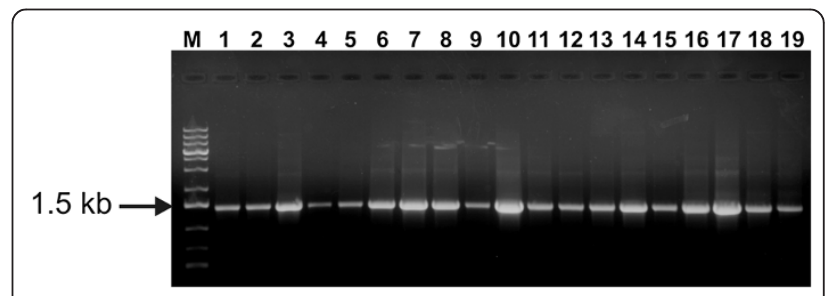

Figure 2 Confirmation of the presence of inserts. PCR was carried out using as template plasmid DNA isolated from randomly selected colonies derived from the PPCV-B (1-10) or PPCV-T (11-19) ligation systems. M-GeneRuler 1 kb plus (Fermentas). 
$\mathrm{MgCl}_{2}, 10 \mathrm{mM}$ DTT, $66 \mu \mathrm{M}$ ATP), and incubation was carried out at $16^{\circ} \mathrm{C}$ for $16 \mathrm{~h}$ following transformation of E. coli $\mathrm{DH} 5 \alpha$ cells.

\section{Results and discussion}

For vector construction, a minimal polylinker was designed (Figure 1A) with the inclusion of restriction sites for XcmI, which produce 3 ' $-\mathrm{T}$ overhangs that can be used for cloning PCR products derived from amplification by Taq polymerase, and EcoRV, which yields blunt-ends suitable for cloning PCR products generated by $P f u$ DNA polymerases. It is argued that the use of $X \mathrm{cmI}$ is limited because vectors incubated with this enzyme are often partially digested leading to a high background of non-recombinant transformants [Xuejun et al. 2002]. This issue was solved by the insertion of a stuffer DNA sequence large enough to be easily separated by gel electrophoresis [Gu \& Ye 2011; Jo \& Jo 2001]. The new polylinker still allows blue/white selection because the lacZ $\alpha$ reading frame is reestablished upon religation of the vector after removal of the stuffer DNA (Figure 1A). When vectors digested with EcoRV are religated the lac $Z \alpha$ reading frame is restored thus rendering the cells blue, whereas vectors digested with XcmI can only yield blue colonies if both T-overhangs are lost prior to religation.

For stuffer DNA, a fragment of the yeast URA3 gene was amplified containing EcoRV and $X c m \mathrm{I}$ sites for amplicon ligation and $S a c \mathrm{I}$ and $K p n \mathrm{I}$ for cloning into pBlueScript $^{\circ}$ II KS digested with the same enzymes (Figure 1A). A selected clone was digested with different enzymes to confirm the presence of the stuffer DNA: EcoRV (558 bp), SacI + KpnI (570 bp), XcmI (534 bp) (Figure 1B). The resulting vector was named pPCV (Figure 1C). This vector was digested either with $X c m \mathrm{I}$ or EcoRV and the $\sim 2.9 \mathrm{~kb}$ versions of the linearized vectors were named $\mathrm{pPCV}-\mathrm{T}$ and $\mathrm{pPCV}-\mathrm{B}$, respectively (Figure 1C).

To test the efficiency of the resulting vectors, a yeast LEU2 gene fragment was amplified by using Phusion or Taq polymerase and the resulting amplicons $(\sim 1.4 \mathrm{~kb})$ were ligated into PPCV-B and PPCV-T, respectively. The results of bacterial transformation are presented on Table 1 and the presence of inserts was assessed by PCR using primers 5-leud and 3-leud (Figure 2). The low percentage of white colonies observed when the pPCV-B system was used is explained by the fact that ligation of blunt-ended molecules is generally more difficult than sticky-ends. Nonetheless, a high percentage $(83.3 \%)$ of white colonies had inserts. As for the pPCV-T system, most of the white colonies (90.0\%) observed had inserts. All other false positives can be explained by the loss of one T-overhang following religation, which results in the loss of original $l a c Z \alpha$ reading frame as has been previously observed [Arashi-Heese et al. 1999].
The results shown in this work show that pPCV can be successfully used for high efficiency cloning of amplicons. It provides in the same cloning platform two important advantages: i) the ability to clone PCR products derived from different DNA polymerases still allowing blue/white selection and, ii) its minimal polylinker prevents undesirable restriction sites at the ends of cloned amplicon after subcloning. Plasmid pPCV is available upon request.

\section{Competing interests}

The authors declare that they have no competing interests.

\section{Authors'contribution}

CRJ and ANPB carried out all the experiments described in this study as part of their MSC thesis and undergraduate training, respectively. VCBR, LMPP and FAGT acted as mentors during different stages of the project. All authors have read and approved the final manuscript.

\section{Acknowledgements}

Christiane Ribeiro Janner, Ana Lívia e Palos Brito had a fellowship from CNPq. This work was supported by FAPDF (grant 193.000.582/2009) and CNPq.

Received: 9 August 2013 Accepted: 31 August 2013 Published: 5 September 2013

\section{References}

Alani E, Cao L, Kleckner N (1987) A method for gene disruption that allows repeated use of URA3 selection in the construction of multiply disrupted yeast strains. Genetics 116:541-545

Arashi-Heese N, Miwa M, Shibata H (1999) Xcml site-containing vector for direct cloning and in vitro transcription of PCR product. Mol Biotechnol $12: 281-283$

Borovkov AY, Rivkin MI (1997) Xcml-containing vector for direct cloning of PCR products. Biotechniques 22:812-814

Clark JM (1988) Novel non-templated nucleotide addition reactions catalyzed by procaryotic and eucaryotic DNA polymerases. Nucleic Acids Res 16:9677-9686

Dimov SG (2012) pSDTV vector: a modification of the pBluescript SK + plasmid in order to perform PCR-fragments TA-cloning using Eam 1105 I restriction endonuclease. Mol Biol Rep 39:6133-6139

Gu J, Ye C (2011) pYEMF, a pUC18-derived Xcml T-vector for efficient cloning of PCR products. Mol Biotechnol 47:229-233

Harrison J, Molloy PL, Clark SJ (1994) Direct cloning of polymerase chain reaction products in an Xcml T-vector. Anal Biochem 216:235-236

Holton TA, Graham MW (1991) A simple and efficient method for direct cloning of PCR products using ddT-tailed vectors. Nucleic Acids Res 19:1156

Jo C, Jo SA (2001) A simple method to construct T-vectors using Xcml cassettes amplified by nonspecific PCR. Plasmid 45:37-40

Jun SY, Yoon SJ, Kang SH (2010) One-step preparation of a TA-cloning vector from a specially designed parent plasmid containing a dual lac $Z$ gene system. Mol Biotechnol 45:9-14

Mortimer RK, Johnston JR (1986) Genealogy of principal strains of the yeast genetic stock center. Genetics 113:35-43

Xuejun H, Zhichao Z, Yongming B, Qing Y, Lijia A (2002) An expeditious method for constructing T-vectors using Eam 1105 I cassettes. Plant Mol Biol Rep 20:189

doi:10.1186/2193-1801-2-441

Cite this article as: Janner et al:: pPCV, a versatile vector for cloning PCR products. SpringerPlus 2013 2:441. 